\title{
Association of CDH1 -160 C $\rightarrow$ A and -347 G $\rightarrow$ GA polymorphisms and expression of E-cadherin and gastric cancer: A case-control study
}

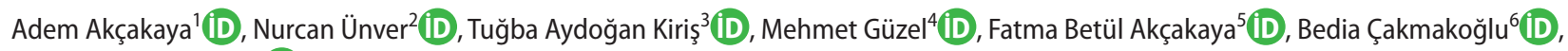
Mustafa Hasbahçeci ${ }^{7,8}$ (D)

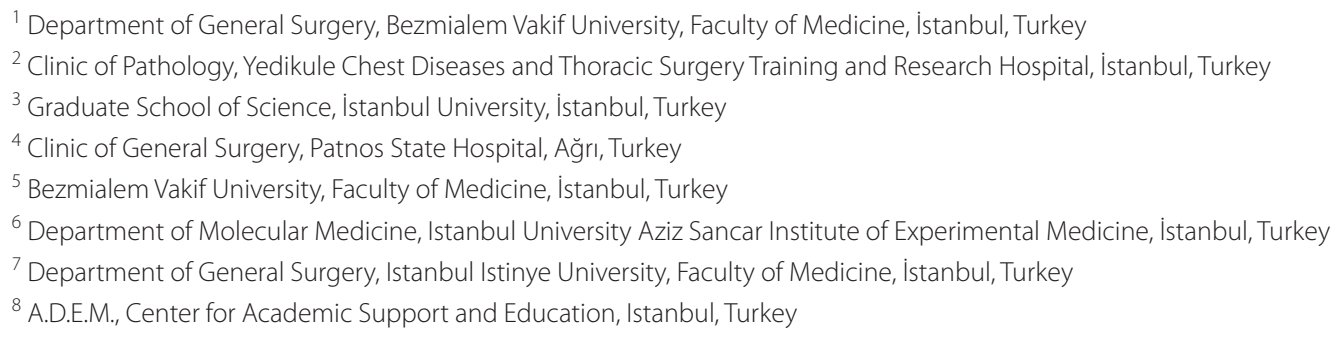

\section{ABSTRACT}

Objective: The loss of function of the E-cadherin $(\mathrm{CDH} 1)$ gene with $-160 \mathrm{C} \rightarrow \mathrm{A}$ and $-347 \mathrm{G} \rightarrow \mathrm{GA}$ polymorphisms is regarded as a critical step for gastric cancer. It was aimed to investigate possible association of these polymorphisms and immunoexpression of E-cadherin with gastric cancer.

Material and Methods: Gastric adenocarcinoma patients and individuals with benign gastric pathologies were included in this case-control study. Demographic data and pathological findings were recorded. Immunohistochemical staining of E-cadherin expression and analysis of $-160 \mathrm{C} \rightarrow \mathrm{A}$ and -347 $\mathrm{G} \rightarrow \mathrm{GA}$ polymorphisms were done. Differences between allele frequencies of $-160 \mathrm{C} \rightarrow \mathrm{A}$ and $-347 \mathrm{G} \rightarrow \mathrm{GA}$ polymorphisms and expression of $\mathrm{E}-\mathrm{cadherin}$ were the primary outcomes.

Results: There were 78 gastric cancer patients (Group A) and 113 individuals with benign gastric pathologies (Group B). The number of male patients and mean age were higher in Group A ( $p<0.001$ ). $-160 \mathrm{C} \rightarrow \mathrm{A}$ and $347 \mathrm{G} \rightarrow \mathrm{GA}$ polymorphisms and their allelic distributions showed no difference between the groups ( $p>0.05$ for all). There was a significant association between $-160 C \rightarrow$ A polymorphism and grade of E-cadherin expression ( $p=0.013$ ). There were no significant differences between survival rates with $-160 \mathrm{C} \rightarrow \mathrm{A}, 347 \mathrm{G} \rightarrow \mathrm{GA}$ and intensity of $\mathrm{E}$-cadherin expression $(\mathrm{p}>0.05$ for all). There was no significant association between $-160 \mathrm{C} \rightarrow \mathrm{A}$ and $-347 \mathrm{G} \rightarrow \mathrm{GA}$ polymorphisms and gastric cancer.

Conclusion: There was no impact of E-cadherin expression on tumoral features and survival in gastric cancer. $-160 \mathrm{C} \rightarrow \mathrm{A}$ polymorphism may influence the expression of E-cadherin in gastric cancer.

Keywords: $\mathrm{CDH} 1$ polymorphisms, E-cadherin, gastric carcinoma, immunohistochemical expression, survival

Cite this article as: Akçakaya A, Ünver N, Aydoğan Kiriş T, Güzel M, Akçakaya FB, Çakmakoğlu B, et al. Association of $\mathrm{CDH} 1-160 \mathrm{C} \rightarrow \mathrm{A}$ and $-347 \mathrm{G} \rightarrow \mathrm{GA}$ polymorphisms and expression of E-cadherin and gastric cancer: A case-control study. Turk J Surg 2021; 37 (1): 41-48.

\section{Corresponding Author} Mustafa Hasbahçeci

E-mail: hasbahceci@yahoo.com

Received: 14.11 .2020

Accepted: 05.03 .2021

Available Online Date: 22.03.2021

o Copyright 2021 by Turkish Surgical Society Available online at www.turkjsurg.com

DOI: 10.47717/turkjsurg.2021.5097

\section{INTRODUCTION}

Loss of E-Cadherin encoded by CDH1 gene is known to cause loss of cellular differentiation and intercellular adhesion, which is an early step in neoplastic processes $(1,2)$. Therefore, $\mathrm{CDH} 1$ is regarded as a causative factor for several types of tumors including gastric cancer (3).

Single nucleotide polymorphisms (SNP) of $\mathrm{CDH} 1$ gene are associated with an increased risk of gastric cancer (4). Among these, $-160 \mathrm{C} \rightarrow \mathrm{A}$ and $-347 \mathrm{G} \rightarrow \mathrm{GA}$ are SNPs located in the promoter region of $\mathrm{CDH} 1$ both of which decrease the transcription efficiency of $\mathrm{CDH1}$ gene (3-8). The possible association of these SNPs with gastric cancer has been studied in previous reports (5). Although $\mathrm{CDH} 1$ mutations are usually associated with hereditary and/or sporadic diffuse gastric cancer, some reports have also shown these mutations in intestinal gastric cancer cases (9-11). However, conflicting results regarding association and prognostic impact of SNPS were recorded in different ethnic populations (1, 2, 12-15). In addition, the role of these polymorphisms on the expression of E-cadherin in gastric cancer has not 
been studied. We aimed to investigate the possible association of $-160 \mathrm{C} \rightarrow \mathrm{A}$ and $-347 \mathrm{G} \rightarrow \mathrm{GA}$ polymorphisms in patients with gastric cancer, immunoexpression of E-cadherin and their impact on prognosis of the gastric cancer patients in the present study.

\section{MATERIAL and METHODS}

\section{Study Design}

This was a hospital-based case-control study including patients with gastric adenocarcinoma and individuals who required endoscopic evaluation due to dyspeptic symptoms.

\section{Compliance With Ethical Standards}

Local ethics committee approval (71306642/050-01-04/29622.10.2014) was taken. Written consent was obtained from all patients and from individuals with benign gastric pathologies. The study was performed in accordance with the principles of the Declaration of Helsinki.

\section{Setting and Participants}

Between January 2015 and April 2018, a series of 125 gastric cancer patients who underwent surgical treatment was included.

Inclusion criteria were gastrectomy for adenocarcinoma with curative intent and the procurement of blood samples. Diffuse or intestinal type all gastric adenocarcinomas were included. Patients with palliative gastrectomy and metastatic disease ( $\mathrm{n}=$ 18), unsuitable tumor blocks and slides for immunohistochemical studies ( $n=3)$, secondary or recurrent gastric adenocarcinoma $(n=6)$, lack of laboratory $(n=16)$ and clinical data $(n=4)$ were excluded.

By random sampling, individuals with benign gastric pathologies via biopsy with no history of previous cancer, history of cancer in family diagnosed in the first or second degree relatives, and active gastric and duodenal ulcers were recruited from our endoscopy center. Therefore, the participants whose endoscopic evaluation was performed on the first working day of each month during the same interval were consecutively included. As a result, 78 gastric cancer patients (Group A) and 113 individuals with benign gastric pathologies (control group) (Group B) were included in the study. For the control group, these pathologies included chronic gastritis ( $n=103,91.2 \%)$, hiperplastic polyp ( $n=$ $7,6.1 \%)$ and fundic polyp ( $n=3,2.7 \%)$.

\section{Variables}

Demographic data and pathological findings including tumor diameter, tumor $(\mathrm{T})$ and lymph node $(\mathrm{N})$ stages, differentiation grade, lymphatic, vascular and perineural invasions and E-cadherin expressions were recorded (16). Patients with signet ring cell and mucinous pathology were grouped as poorly differentiated histology.

\section{E-Cadherin Expression by Immunohistochemistry}

Four-micrometer-thick $(4 \mu)$ sections of formalin-fixed paraffin embedded tissues were placed on 3-aminopropyletxylene-covered slides.

Subsequently, they were stained with rabbit polyclonal Biocare Medical E-Cadherin antibody in accordance with the manufacturer's protocol. Briefly, staining was performed on Ventana BenchMark Ultra (Ventana Medical Systems Inc.).

The staining protocol included cell conditioning 1 for 60 min, pre-peroxidase inhibition and primary antibody incubation for $32 \mathrm{~min}$ at $37^{\circ} \mathrm{C}$. UltraView Universal DAB Detection Kit (Ventana Medical Systems) was used to detect e-Cadherin protein expression. Tissues were counterstained with Hematoxylin for 16 min and bluing reagent for $4 \mathrm{~min}$. Using the internal positive (normal gastric mucosa) and negative staining controls (lymphocytes), the estimated percentage of the positively stained tumor cells were reported as a scale with three grades: $<10 \%$ as $0,10-90 \%$ as +1 and $>90 \%$ as +2 . Grouping was performed 0 to $1+$ grade as "low" staining (Figure 1-A) and +2 grade as "high" staining for E-cadherin (Figures 1-B, C) $(17,18)$.

An experienced pathologist performed all histopathological evaluations and E-cadherin expressions.
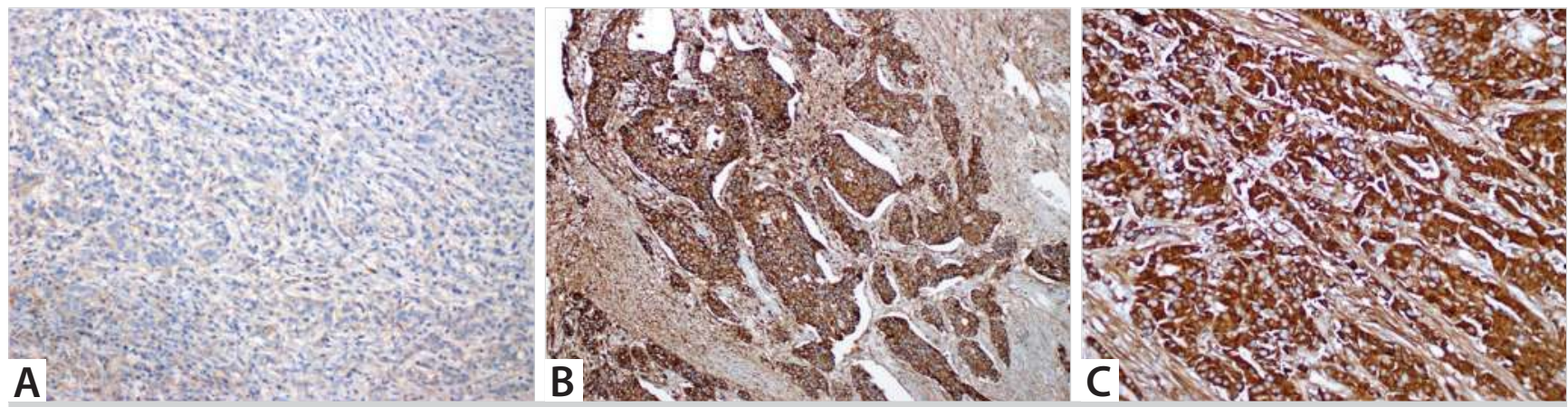

Figure 1. A. Low staining in the tumoral cells in poorly cohesive gastric carcinoma (including signet ring cell) with E-cadherin marker in $I \mathrm{HC}$ staining (magnification X200) B. High staining in gastric adenocarcinoma cells with E-Cadherin (magnification X200) C. High staining in gastric adenocarcinoma cells with E-Cadherin (magnification X200). 

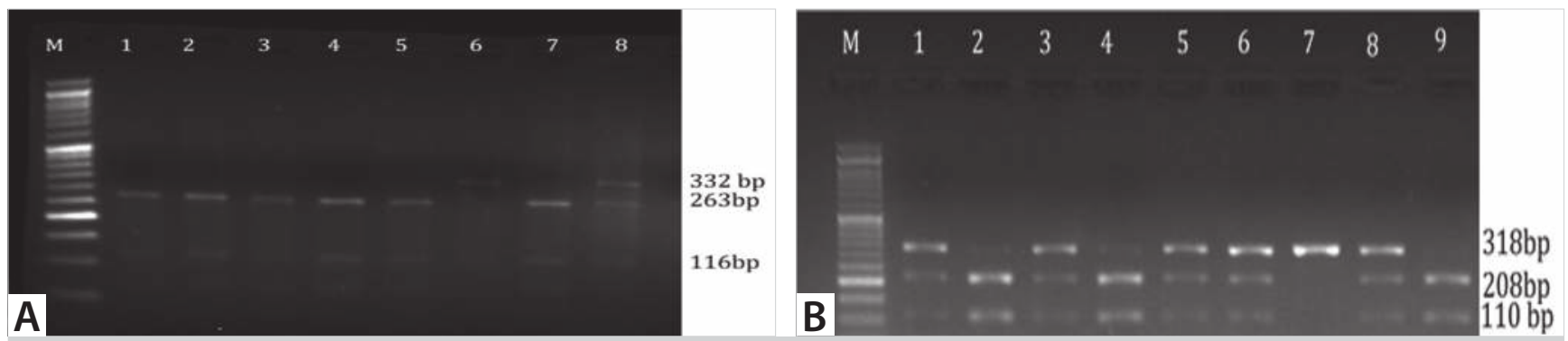

Figure 2. A. Genotyping of E-cadherin, the -347 G $\rightarrow$ GA. M: 50bp marker. Lane 1, 2, 3, 4, 5 and 7: GA/GA genotype. Lane 6: G/G genotype. Lane 8: G/ GA genotype. B. Genotyping of E-cadherin, the -160 C $\rightarrow$ A. M: 50bp marker. Lane 7: C/C genotype. Lane : 1, 3, 5, 6, 8: C/A genotype. Lane 2, 4, 9: A/A genotype.

\section{Polymorphism Analysis}

Genomic DNA samples were extracted from blood samples using white blood cells method of Miller et al. (19) After DNA sample isolation, DNA samples were amplified by polymerase chain reaction for CDH1 -160C/A (rs16260) and CDH1 -347G/ GA (rs5030625). Forward- 5'-TGATCCCAGGTCTTAGTGAG-3' and reverse- 5'-AGTCTGAACTGACTT CCGCA-3' were used primers for $\mathrm{CDH} 1$-160C/A (20). For CDH1 -347G/GA, forward-5'-GCCCCGACTTGTCTCTCTAC-3' and reverse- 5'-GGCCACAGCCAATCAGCA-3' were used (21). Restriction fragment length polymorphism analysis was performed using appropriate enzymes. Collected products of CDH1 -160C/A and CDH1 -347G/GA were cut using BstEll (NEB, R0162S) and Banll (NEB, R0119S) restriction enzymes ( $15 \mathrm{~min}, 60^{\circ} \mathrm{C}$ and $2 \mathrm{~h}, 37^{\circ} \mathrm{C}$, respectively) and studied in agarose gel using electrophoresis ( $2 \%$ agarose gel, $25 \mathrm{~min}$ and 4\% nusieve agarose gel, 40 min, respectively) (Figures 2-A, B).

As a standard approach, negative and positive samples were used during each gel loading, and the experiments were repeated at least twice.

\section{Follow-Up}

Follow-up examinations were performed in every 3 months during the first two years and every six months during the following years. Location of recurrences was classified as peritoneal and local recurrence, hepatic and other distant metastasis. End of January, 2019 or the date of death for the relevant patients was the last follow-up date for the study yielding a mean period of $22.4 \pm 12.8$ months. During this period, three patients (three out of 78 (3.8\%)) were lost for survival analysis. Therefore, median follow-up for all patients ( $n=75$ ) and the patients who survived $(n=41)$ was 18 months (ranging from 4 to 49 months) and 30 months (ranging from 14 to 49 months), respectively.

\section{Statistical Analysis}

Distribution of $-160 \mathrm{C} \rightarrow \mathrm{A}$ and $-347 \mathrm{G} \rightarrow \mathrm{GA}$ polymorphisms in gastric cancer patients with regard to demographic and clinical features was the primary outcome in gastric cancer patients and the individuals in the control group. Differences between allele frequencies of $-160 \mathrm{C} \rightarrow \mathrm{A}$ and $-347 \mathrm{G} \rightarrow \mathrm{GA}$ polymorphisms were the secondary outcome. Normally-distributed continuous variables were expressed as mean \pm standard deviation (SD). Categorical variables were expressed as frequencies and percentages. All statistical analyses were performed using the Statistical Package for the Social Sciences (SPSS) 15.0 for Windows (SPSS, Inc., Chicago, IL, USA). The Kolmogorov-Smirnov test was used to evaluate the normality of distribution. Hardy-Weinberg equilibrium was also tested comparing observed frequencies in patients with gastric cancer with expected frequencies in control group. $-160 \mathrm{C} \rightarrow \mathrm{A}$ and $-347 \mathrm{G} \rightarrow \mathrm{GA}$ polymorphisms were analysed by using Chi-square test. Haplotype analysis was performed using Haploview (Version 4.2, Broad Institute of MIT and Harvard, USA, 2009). Logistic regression analysis was used to assess the impact of $-160 \mathrm{C} \rightarrow \mathrm{A}$ and $-347 \mathrm{G} \rightarrow \mathrm{GA}$ polymorphisms on the development of gastric cancer by using Odds ratio (OR) with $95 \%$ Confidence Interval (Cl). Association of $-160 \mathrm{C} \rightarrow \mathrm{A}$ and $-347 \mathrm{G} \rightarrow \mathrm{GA}$ polymorphisms and expression of E-cadherin to demographic and pathological features was analysed using Chi-square test, Student's t test, and Fisher's exact test. Gastric cancer outcomes such as disease free survival (DFS) and overall survival (OS) were analysed using Cox regression analysis and Kaplan-Meier curves, and a log rank test was used for the comparison of the groups according to survival rates. All statistical tests were two-sided, and a $p$ value $<0.05$ was considered statistically significant.

\section{RESULTS}

\section{Study Groups}

There were 78 gastric cancer patients in Group A, and 113 individuals in Group B (the control group). Mean age was $59.1 \pm 11.1$ years and $50.3 \pm 15.3$ years in Group A and B, respectively. There were significant differences regarding age and sex between the groups ( $p<0.001$ for both) (Table 1).

Mean diameter of the tumors was $6 \pm 3.4 \mathrm{~cm}$. T4 and N3 were the most common stages with $47.5 \%$ and $50 \%$, respectively. Poorly differentiated histology was detected in 50 patients (64.1\%).

\section{Genotype Distribution}

Hardy-Weinberg analysis showed that $p$ value for $-160 \mathrm{C} \rightarrow \mathrm{A}$ and $347 \mathrm{G} \rightarrow \mathrm{GA}$ polymorphisms were $<0.001$ (x2: 33.17) and 0.450 
Table 1. Demographic data and distribution of $-160 C \rightarrow A$ and $-347 G \rightarrow G A$ polymorphisms

\begin{tabular}{|c|c|c|c|c|c|c|}
\hline Variable & & Overall $(n=191)$ & Group A $(n=78)$ & Group $B(n=113)$ & Chi-square & $p$ \\
\hline Age $^{*}$ & & & $59.1 \pm 11$ & $50.3 \pm 15$ & & 0.0001 \\
\hline Sex (Male/female) & & $105 / 86$ & $61 / 17$ & $44 / 69$ & & 0.0001 \\
\hline \multirow[t]{3}{*}{$-160 \mathrm{C} \rightarrow \mathrm{A} t$} & $\mathrm{C} / \mathrm{C}$ & $28(14.7)$ & $13(16.7)$ & $15(13.3)$ & 4.488 & 0.130 \\
\hline & $\mathrm{C} / \mathrm{A}$ & $137(71.7)$ & $50(64.1)$ & $87(77)$ & & \\
\hline & $A / A$ & $26(13.6)$ & $15(19.2)$ & $11(9.7)$ & & \\
\hline \multirow[t]{3}{*}{$-347 \mathrm{G} \rightarrow \mathrm{GA} \dagger$} & $\mathrm{G} / \mathrm{G}$ & $149(78)$ & $60(76.9)$ & $89(78.8)$ & 2.929 & 0.345 \\
\hline & $\mathrm{G} / \mathrm{GA}$ & $40(20.9)$ & $16(20.5)$ & $24(21.2)$ & & \\
\hline & GA/GA & $2(1.1)$ & $2(2.6)$ & $0(0)$ & & \\
\hline \multirow[t]{2}{*}{$-160 \mathrm{C} \rightarrow \mathrm{A} \dagger$} & Callele & $193(50.5)$ & $76(48.7)$ & $117(51.8)$ & 0.533 & 0.451 \\
\hline & A allele & $189(49.5)$ & $80(51.3)$ & $109(48.2)$ & & \\
\hline \multirow[t]{2}{*}{$-347 \mathrm{G} \rightarrow \mathrm{GA} \dagger$} & G allele & $338(88.5)$ & $136(87.2)$ & $202(89.4)$ & 0.518 & 0.439 \\
\hline & A allele & $44(11.5)$ & $20(12.8)$ & 24 (10.6) & & \\
\hline
\end{tabular}

Table 2. Haplotype analysis of $\mathrm{CDH} 1$ polymorphisms in the study groups

\begin{tabular}{|l|c|c|c|c|}
\hline Haplotype associations & Frequency (\%) & Patient, control (\%) & Chi square & p \\
\hline-347 G: -160 C & 0.494 & $0.469,0.510$ & 0.631 & 0.427 \\
\hline-347 G: -160 A & 0.391 & $0.403,0.383$ & 0.145 & 0.704 \\
\hline-347 GA: -160 A & 0.103 & $0.110,0.099$ & 0.125 & 0.724 \\
\hline-347 GA: $-160 C$ & 0.012 & $0.018,0.007$ & 0.934 & 0.339 \\
\hline
\end{tabular}

Table 3. Association of $-160 \mathrm{C} \rightarrow \mathrm{A}$ and $-347 \mathrm{G} \rightarrow \mathrm{GA}$ polymorphisms with intensity of E-cadherin expression

\begin{tabular}{|c|c|c|c|c|c|}
\hline \multirow[b]{2}{*}{ Genotype } & & \multicolumn{2}{|c|}{ E-cadherin expression $\dagger$} & \multirow[b]{2}{*}{ Chi-square } & \multirow[b]{2}{*}{$p$} \\
\hline & & Low & High & & \\
\hline \multirow[t]{3}{*}{$-160 C \rightarrow A$} & $\mathrm{C} / \mathrm{C}$ & $3(23.1)$ & $10(76.9)$ & 10.157 & 0.013 \\
\hline & $C / A$ & $27(54)$ & $23(46)$ & & \\
\hline & $\mathrm{A} / \mathrm{A}$ & $12(80)$ & $3(36)$ & & \\
\hline \multirow[t]{3}{*}{$-347 \mathrm{G} \rightarrow \mathrm{GA}$} & $\mathrm{G} / \mathrm{G}$ & $34(43.6)$ & $26(33.3)$ & 2.706 & 0.679 \\
\hline & G/GA & $8(10.25)$ & $8(10.25)$ & & \\
\hline & $\mathrm{GA} / \mathrm{GA}$ & $1(1.3)$ & $1(1.3)$ & & \\
\hline
\end{tabular}

(x2: 1.60) for Group B, respectively. For Group A, p values of 0.044 (x2: 6.24) and 0.768 (x2: 0.53) were calculated for $-160 \mathrm{C} \rightarrow \mathrm{A}$ and $347 \mathrm{G} \rightarrow \mathrm{GA}$ polymorphisms, respectively. Haplotype associations of the polymorphisms were not statistically significant in Group A and Group B (Table 2) (D':0.799, LOD:2.61, r2:0.085).

Distribution of $-160 \mathrm{C} \rightarrow \mathrm{A}$ and $-347 \mathrm{G} \rightarrow \mathrm{GA}$ polymorphisms in Group A and Group B is shown in Table 1. None of the polymorphisms (-160 C $\rightarrow$ A and $347 \mathrm{G} \rightarrow \mathrm{GA})$ and allelic distribution showed significant difference in the genotype. Logistic regression analysis showed no significant association for risk of gastric cancer considering variant genotypes of
$-160 \mathrm{C} \rightarrow \mathrm{A}$ and $347 \mathrm{G} \rightarrow \mathrm{GA}$ polymorphisms (OR: 0.832, p: 0.520, 95\% Cl: 0.475-1.458 and OR: 0.844, p: 0.614, 95\% Cl: 0.436-1.633, respectively).

\section{Genotype Distribution and Tumoral Features of Gastric Cancer}

Only significant association was between $-160 \mathrm{C} \rightarrow$ A polymorphism and grade of $E$-cadherin expression ( $p=0.013$ ) (Table 3). There were more patients with $\mathrm{A} / \mathrm{A}$ and $\mathrm{C} / \mathrm{C}$ haplotypes in patients with low and high E-Cadherin expressions, respectively. There was no significant association between tumor diameter, 
T stage, N stage, grade, lymphovascular invasion, perineural invasion and grade of E-cadherin expression and the polymorphisms ( $p>0.05$ for all).

\section{Immunoexpression of E-cadherin}

Distributions of E-cadherin positive staining were grade 0 in 17 (21.8\%), grade $1+$ in 25 (32.0\%) and grade $2+$ in 36 (46.2\%). Low and high staining for E-cadherin expression was detected in 42 (53.8\%) and 36 (46.2\%) patients, respectively. There was no signicant correlation between the intensity of E-cadherin expression and age, sex, diameter, T stage, N stage, grade, lymphovascular invasion and perineural invasion ( $p>0.05$ for all).

\section{Survival and Recurrence}

Twenty-nine recurrences (38.7\%) and 34 deaths with a mortality rate of $45.3 \%$ were detected. Mean length of DFS and OS were $20.3 \pm 13.9$ months and $22.4 \pm 12.8$ months, respectively. Overall survival rate at the end of the follow up time was $54.7 \%$. Cox regression analysis revealed no significant differences between survival rates of the patients with $-160 \mathrm{C} \rightarrow \mathrm{A}$ and -347 $\mathrm{G} \rightarrow \mathrm{GA}$ polymorphisms and intensity of E-cadherin expression $(p=0.253, p=0.639$ and $p=0.625$, respectively). Kaplan Meier analysis showed similar OS for all (log rank, $p=0.219, p=0.468$ and $p=0.648$ for $O S$, respectively). Most common locations for recurrences were hepatic and peritoneal carcinomatosis in 12 (41.4\%) and 11 patients (37.9\%), respectively. There was no significant association between DFS and $-160 \mathrm{C} \rightarrow \mathrm{A},-347 \mathrm{G} \rightarrow \mathrm{GA}$ and grades of E-cadherin ( $p>0.05$ for all).

\section{DISCUSSION}

This case-control study showed that there was no significant association between $-160 \mathrm{C} \rightarrow \mathrm{A}$ and $-347 \mathrm{G} \rightarrow \mathrm{GA}$ polymorphisms and development of gastric cancer. Presence of significant differences between the groups with regard to age and sex and dysequilibrium of $-160 \mathrm{C} \rightarrow$ A polymorphism might be important. Although a significant association was detected between -160 C $\rightarrow$ A polymorphism and grade of E-cadherin expression, their impact on survival of gastric cancer has not been shown.

In this study, we found a significant deviation from Hardy-Weinberg equilibrium both in the control group and the patients. Although it has been regarded as an evidence of genotyping error, there have been several explanations including selection bias for controls, relatively small sample or population sizes and real genetic effects caused by assortative mating i.e., selection, ran-random mating, or migration, inbreeding caused by consanguinity and population stratification (22-24). An excess of heterozygosity (homozygote deficiency) can be due to copy number variations while population stratification always leads to heterozygote deficit. Wang et. al. (25) have reported that healthy individuals as controls may not accurately represent overall population when disease is common in population leading type I error probabilities for primary disease and/or secondary phenotype-associated genetic markers. Therefore, our results in relation with $-160 \mathrm{C} \rightarrow$ A polymorphism should be considered based on these explanations. In order to overcome such problems for case-control studies, use of pooled control samples and extended likelihood-based approaches including Chen and Chatterjee's methods and extended mixture Hardy-Weinberg proportion tests result in validity of Hardy-Weinberg equilibrium (23-25). Calculation of Hardy-Weinberg equilibrium along with genotype distribution data has been recommended (26). In addition, although it is costly and useful only in specific genotyping errors caused by technical artifacts, repeated genotyping of the same probands can also be preferred. Therefore, future case-control studies with appropriate statistics and population genetic concepts are needed.

Polymorphisms within gene promoter regions may cause profound effects on the transcriptional efficiency of the genes (22). It has been known that there were more than one hundred different $\mathrm{CDH} 1$ gene polymorphisms in association with gastric cancer (27). Most of these polymorphisms were non-missense mutations and detected in patients from low-risk areas for gastric cancer. Huge inconsistency in the polymorphism of -160 C $\rightarrow$ A was found in the previous studies (22). It was suggested that ethnic differences may have a role in association with absence or presence of $-160 \mathrm{C} \rightarrow \mathrm{A}$ polymorphism $(13,22,28)$. Although presence of such associations was shown especially in Asian populations (6-8), other studies have failed to prove effect of $\mathrm{CDH} 1$ gene polymorphisms $(4,12,13)$. There was a significant recessive effect of $A$ allele for gastric cancer only in Asian studies in the meta-analyses of Cui and Li $(2,28)$. In addition, researchers have reported that significant differences were usually based on studies with a total number of patients and controls less than 300 (2). However, another meta-analysis failed to confirm association between $-160 \mathrm{C} \rightarrow$ A polymorphism and risk of gastric cancer (29). Therefore, type and frequency of different $\mathrm{CDH} 1$ mutations should be evaluated by considering ethnic and geographic differences.

Researchers have suggested that sex distribution and different age groups may also affect results of such polymorphism studies $(1,15)$. Due to significant differences in the groups regarding sex distribution, we could not reach on a conclusion. Previous studies have also reported that there were significant differences in relation with types of gastric cancer as sporadic diffuse or intestinal and sex distribution $(1,30)$. However, meta-analyses and several studies have failed to show such associations $(2,13)$. Therefore, we analysed all gastric cancer types as one group in the present study.

We examined $-160 \mathrm{C} \rightarrow \mathrm{A}$ and $-347 \mathrm{G} \rightarrow \mathrm{GA}$ polymorphisms. However, we found no significant association between these two polymorphisms and in the development of gastric cancer. Chu et al. (1), Borges et al. (8) and Al-Moundhri et al. (7) have shown 
a significant association between $-160 \mathrm{C} \rightarrow$ A polymorphism and gastric cancer in Taiwanese, Brazilian and Omani populations, respectively. Lin et al. (30) have shown the association of $\mathrm{CDH} 1$ rs121964871 C>G polymorphism with susceptibility of gastric cancer. Akbas et al. (15) have established that

$-160 \mathrm{C} \rightarrow$ A polymorphism was not associated with gastric and esophageal cancers in a Turkish population. Although the patients in Akbas's study (15) comprised of both gastric and esophageal cancers with adenocarcinoma and squamous cell carcinoma, subgroup analysis has not been performed. Therefore, our study is the first study to evaluate effect of $\mathrm{CDH} 1$ polymorphisms on gastric adenocarcinoma patients in a Turkish population.

Controversial results have been reported regarding -347 G $\rightarrow$ GA polymorphism in gastric cancer. Borges et al. (8) have reported a higher risk of gastric cancer in patients with 347 GA allele. Chen et al. (6) have found no association with gastric cancer risk in accordance with the present study. Therefore, due to detection of controversial results between studies performed in different parts of the world may necessitate future studies with larger sample sizes.

Abnormal expression of E-cadherin has been previously studied (17). In these studies, abnormal expression was shown to be between $38 \%$ to $57 \%$. In the present study, rate was $53.8 \%$ in accordance with others. Although Torabizadeh et al. (17) have reported a significant correlation between abnormal expression of E-cadherin and other tumoral features, only significant association was between $-160 \mathrm{C} \rightarrow$ A polymorphism and staining intensity of E-cadherin expression in the present study. In previous studies, E-cadherin mutation was regarded as a predictive factor for tumor invasiveness, however, we found no such association in our study (31).

Zhang et al. (29) have found no significant associations of -160 $C \rightarrow A$ and -347 del $\rightarrow$ A polymorphisms on survival contrary to $-73 \mathrm{~A} \rightarrow \mathrm{C}$. Membari et al. (4) have reported that patients with AC genotype had lower survival rates. However, low number of patients in this study may prevent the achivement of significant results. In the present study, we found no association between polymorphisms and survival. Large scale studies with longer follow up may clarify possible association between gene polymorphisms and survival of gastric cancer.

It has been shown that low expression of E-cadherin is associated with poor pathological features (18). In addition, low E-cadherin expression has been significantly associated with a lower 5-year-survival. However, we could not find any significant association between intensity of E-cadherin expression and tumoral features. Evaluation of E-cadherin expression has been performed by different methods $(17,18,29-33)$. Therefore, methodological differences may have some impact on this issue.
In this study, we did not find significant differences between survival rates and the overall survival of the patients with $-160 \mathrm{C} \rightarrow$ $A$ and $-347 \mathrm{G} \rightarrow \mathrm{GA}$ polymorphisms and E-cadherin expression intensity. A relatively shorter follow-up time, as 30 months for survivors, might be a factor to reach significant associations. It has been reported that the availability of mortality data for each study is the primary factor affecting the length of follow-up time (34). In this context, this study's follow-up time was not a controllable variable as part of the study design. Shorter follow-up times have been speculated as a significant predictor for rapidly changing health conditions in older populations. Verlato et al. (35) have analyzed short-term (the first two years) and long-term risk factors in gastric cancer. They reported that mortality from recurrence of gastric cancer peaked one year after the curative surgery. In advanced $\mathrm{T}$ and $\mathrm{N}$ stages, there was earlier mortality peaks. Lauren histotype was shown to exert a delayed effect on survival. Based on this study's findings, our follow-up time may be considered adequate due to the presence of advanced $T$ and $\mathrm{N}$ stages in the majority of the cases and the low incidence of diffuse-type gastric cancer (three cases, not given data).

Significant demographic differences between the groups were main limitations in the present study. A relatively shorter follow-up time might be regarded as another limitation. Due to selection criteria of the control group, uncontrollable differences might occur. In addition, inherent selection bias due to presence of dysequilibrium of -160 C $\rightarrow$ A polymorphism was another limitation. A relatively shorter follow-up time might be regarded as another limitation.

\section{CONCLUSION}

Presence or absence of association between $-160 \mathrm{C} \rightarrow \mathrm{A}$ and $-347 \mathrm{G} \rightarrow \mathrm{GA}$ polymorphisms and development of gastric cancer depends on geographic and ethnic variations. $-160 \mathrm{C} \rightarrow \mathrm{A}$ and $-347 \mathrm{G} \rightarrow \mathrm{GA}$ polymorphisms may not play a a major role in this Turkish population. Although there was no impact of E-cadherin expression on tumoral features and survival in gastric cancer, $-160 C \rightarrow$ A polymorphism may influence expression of E-cadherin in gastric cancer.

\section{Source(s) of Support in the Form of Grants}

The study was granted by Bezmialem Vakif University Scientific Research Projects Unit (12.2014/44).

\section{Acknowledgement}

Authors were thankful to Ms. Kadriye Gumus for her kind support for English editing.

Ethics Committee Approval: The approval for this study was obtained from Bezmialem Vakif University Clinical Research ethics Committee (Decision no: 71306642/050-01-04/296 Date: 22.10.2014)

Peer-review: Externally peer-reviewed. 
Author Contributions: Concept - M.H., A.A., B.Ç., N.Ü.; Design - M.H., M.G., A.A.; Supervision - M.H., A.A., B.Ç.; Materials - M.H., A.A., M.G., N.Ü., B.Ç.; Data Collection and/or Processing - All of authors; Analysis and Interpretation - M.H., N.U., B.C.; Literature Review - M.H., F.B.A., M.G.; Writing Manuscript M.H., T.A.K., F.B.A., M.G.; Critical Reviews - M.H., A.A., B.C.

Conflict of Interest: The authors declare that they have no conflict of interest.

Financial Disclosure: The authors declared that this study has received no financial support.

\section{REFERENCES}

1. Chu CM, Chen CJ, Chan DC, Wu HS, Liu YC, Shen CY, et al. CDH1 polymorphisms and haplotypes in sporadic diffuse and intestinal gastric cancer: a case-control study based on direct sequencing analysis. World J Surg Oncol 2014; 12: 80. [CrossRef]

2. Cui Y, Xue H, Lin B, Ni P, Fang JY. A meta-analysis of CDH1 C-160A ge netic polymorphism and gastric cancer risk. DNA Cell Biol 2011; 30: 937-45. [CrossRef]

3. Li LC, Chui RM, Sasaki M, Nakajima K, Perinchery G, Au HC, et al. A single nucleotide polymorphism in the E-cadherin gene promoter alters transcriptional activities. Cancer Res 2000; 60: 873-6. [CrossRef]

4. Menbari MN, Nasseri S, Menbari N, Mehdiabadi R, Alipur Y, Roshani D. The -160 (C>A) CDH1 Gene Promoter Polymorphism and Its Relationship with Survival of Patients with Gastric Cancer in Kurdistan. Asian Pac J Cancer Prev 2017; 18: 1561-5. [CrossRef]

5. Humar B, Graziano F, Cascinu S, Catalano V, Ruzzo AM, Magnani M, et al. Association of $\mathrm{CDH} 1$ haplotypes with susceptibility to sporadic diffuse gastric cancer. Oncogene 2002; 21:8192-5. [CrossRef]

6. Chen B, Zhou Y, Yang P, Liu L, Qin XP, Wu XT. CDH1-160C>A gene polymorphism is an ethnicity-dependent risk factor for gastric cancer. Cytokine 2011; 55: 266-73. [CrossRef]

7. Al-Moundhri MS, Al-Khanbashi M, Al-Kindi M, Al-Nabhani M, Burney IA, Al-Farsi A, et al. Association of E-cadherin (CDH1) gene polymorphisms and gastric cancer risk. World J Gastroenterol 2010; 16: 3432-6. [CrossRef]

8. Borges Bdo N, Santos Eda S, Bastos CE, Pinto LC, Anselmo NP, Qu aresma JAS, et al. Promoter polymorphisms and methylation of E-cadherin (CDH1) and KIT in gastric cancer patients from northern Brazil. Anticancer Res 2010; 30: 2225-33. [CrossRef]

9. Chen QH, Deng W, LiXW, Liu XF, Wang JM, Wang LF, et al. Novel CDH1 germline mutations identified in Chinese gastric cancer patients. World J Gastroenterol 2013; 19: 909-16. [CrossRef]

10. Abou Khouzam R, Molinari C, Salvi S, Marabelli M, Molinaro V, Orioli $D$, et al. Digital PCR identifies changes in CDH1 (E-cadherin) transcription pattern in intestinal-type gastric cancer. Oncotarget 2017; 8: 18811-20. [CrossRef]

11. Bacani JT, Soares M, Zwingerman R, di Nicola N, Senz J, Riddell R, et al. CDH1/E-cadherin germline mutations in early-onset gastric cancer. $J$ Med Genet 2006; 43: 867-72. [CrossRef]

12. Lu Y, Xu YC, Shen J, Yu RB, Niu JY, Guo JT, et al. E-cadherin gene C-160A promoter polymorphism and risk of non-cardia gastric cancer in a Chinese population. World J Gastroenterol 2005; 11:56-60. [CrossRef]

13. Corso G, Berardi A, Marrelli D, Pedrazzani C, Garosi L, Pinto E, et al. CDH1 C-160A promoter polymorphism and gastric cancer risk. Eur J Cancer Prev 2009; 18: 46-49. [CrossRef]
14. Medina-Franco H, Ramos-De la Medina A, Vizcaino G, Medina-Franco JL. Single nucleotide polymorphisms in the promoter region of the E-cadherin gene in gastric cancer: case-control study in a young Mexican population. Ann Surg Oncol 2007; 14: 2246-9. [CrossRef]

15. Akbas H, Uyanikoglu A, Aydogan T, Atay AE, Dilmec F, Cerrah S, et al. E-cadherin (cdh1) gene-160c>a promoter polymorphism and risk of gastric and esophageal cancers. Medica Mediterranea 2013; 29: 671. [CrossRef]

16. Zhang J, Niu Z, Zhou Y, Cao S. A comparison between the seventh and sixth editions of the American Joint Committee on Cancer/ International Union Against classification of gastric cancer. Ann Surg 2013; 257: 81 6. [CrossRef]

17. Torabizadeh Z, Nosrati A, Sajadi Saravi SN, Yazdani Charati J, Janbabai G. Evaluation of E-cadherin expression in gastric cancer and its correlation with clinicopathologic parameters. Int J Hematol Oncol Stem Cell Res 2017; 11: 158-64. [CrossRef]

18. Chu YQ, Ye ZY, Tao HQ, Wang YY, Zhao ZS. Relationship between cell adhesion molecules expression and the biological behavior of gastric carcinoma. World J Gastroenterol 2008; 14: 1990-6. [CrossRef]

19. Miller SA, Dykes DD, Polesky HF. A simple salting out procedure for extracting DNA from human nucleated cells. Nucleic Acids Res 1988; 16 : 1215. [CrossRef]

20. Liu YC, Shen CY, Wu HS, Chan DC, Chen CJ, Yu JC, et al. Helicobacter pylori infection in relation to E-cadherin gene promoter polymorphism and hypermethylation in sporadic gastric carcinomas. World J Gastroenterol 2005; 11:5174-9. [CrossRef]

21. Xiao-Ping Zou, Wei-Jie Dai, Jun Cao. CDH1 promoter polymorphism $(-347 G \rightarrow G A)$ is a possible prognostic factor in sporadic colorectal cancer. World J Gastroenterol 2009; 15: 5340-5. [CrossRef]

22. Zhan Z, Wu J, Zhang JF, Yang YP, Tong S, Shang CB, et al. CDH1 gene polymorphisms, plasma CDH1 levels and risk of gastric cancer in a Chinese population Mol Biol Rep 2012; 39:8107-13. [CrossRef]

23. LeeM. Hardy-Weinberg equilibrium assumptions in case-control tests of genetic association. University of Pittsburgh, thesis for Master of Science. 2009. Available from: URL: http://d-scholarship.pitt.edu/8748/1/ MyoungkeunLee.pdf [CrossRef]

24. Ziegler A, Van Steen K, Wellek S. Investigating Hardy-Weinberg equilibrium in case-control or cohort studies or meta-analysis. Breast Cancer Res Treat 2011; 128:197-201. [CrossRef]

25. Wang J, Shete S. Testing Hardy-Weinberg proportions in a frequencymatched case-control genetic association study. PLOS ONE 2011; 6: e27642. [CrossRef]

26. Yu KD, Di GH, Fan L, Shao ZM. Test of Hardy-Weinberg equilibrium in breast cancer case-control studies: an issue may influence the conclusions. Breast Cancer Res Treat 2009; 117: 675-7. [CrossRef]

27. Corso G, Marrelli D, Pascale V, Vindigni C, Roviello F. Frequency of $\mathrm{CDH1}$ germline mutations in gastric carcinoma coming from highand low-risk areas: metanalysis and systematic review of the literature. BMC Cancer 2012; 12: 8. [CrossRef]

28. Li YL, Tian Z, Zhang JB, Fu BY. CDH1 promoter polymorphism and stomach cancer susceptibility. Mol Biol Rep 2012; 39: 1283-6. [CrossRef]

29. Jiang B, Zhu K, Shao H, Bao C, Ou J, Sun W. Lack of association between the $C D H 1$ polymorphism and gastric cancer susceptibility: a metaanalysis. Sci Rep 2015; 5: 7891. [CrossRef] 
30. Lin Y, Yuan J, Wang L, Wang L, Ma Y, Wang Y, et al. Correlation between SNPs in CDH1 and gastric cancer in Chinese population. Open Med (Wars) 2014; 10:57-62. [CrossRef]

31. Anbiaee R, Mojir Sheibani K, Torbati P, Jaam H. Abnormal expression of e-cadherin in gastric adenocarcinoma, and its correlation with tumor histopathology and helicobacter pylori infection. Iran Red Crescent Med J 2013; 15:218-22. [CrossRef]

32. Saad AA, Awed NM, Abd Elkerim NN, El-Shennawy D, Alfons MA, Elserafy $M E$, et al. Prognostic significance of E-cadherin expression and peripheral blood micrometastasis in gastric carcinoma patients. Ann Surg Oncol 2010; 17: 3059-67. [CrossRef]
33. Lazăr D, Tăban S, Ardeleanu C, Deema A, Spora I, Cornianu M, et al. The immunohistochemical expression of E-cadherin in gastric cancer; correlations with clinicopathological factors and patients' survival. Rom J Morphol Embryol 2008; 49: 459-67. [CrossRef]

34. Meinow B, Kåreholt I, Parker MG, Thorslund M. The effect of the duration of follow-up in mortality analysis: the temporal pattern of different predictors. J Gerontol B Psychol Sci Soc Sci 2004; 59: S181-9. [CrossRef]

35. Verlato G, Marrelli D, Accordini S, Bencivenga M, Di Leo A, Marchet A, et al. Short-term and long-term risk factors in gastric cancer. World J Gastroenterol 2015; 21:6434-43. [CrossRef]

\section{ORIJINAL ÇALIŞMA-ÖZET}

Turk J Surg 2021; 37 (1): 41-48

\section{CDH1 -160 C $\rightarrow$ A ve -347 G $\rightarrow$ GA polimorfizmleri ve E-kaderin ekspresyonunun mide kanseri ile ilişkisi: Bir vaka-kontrol çalışması}

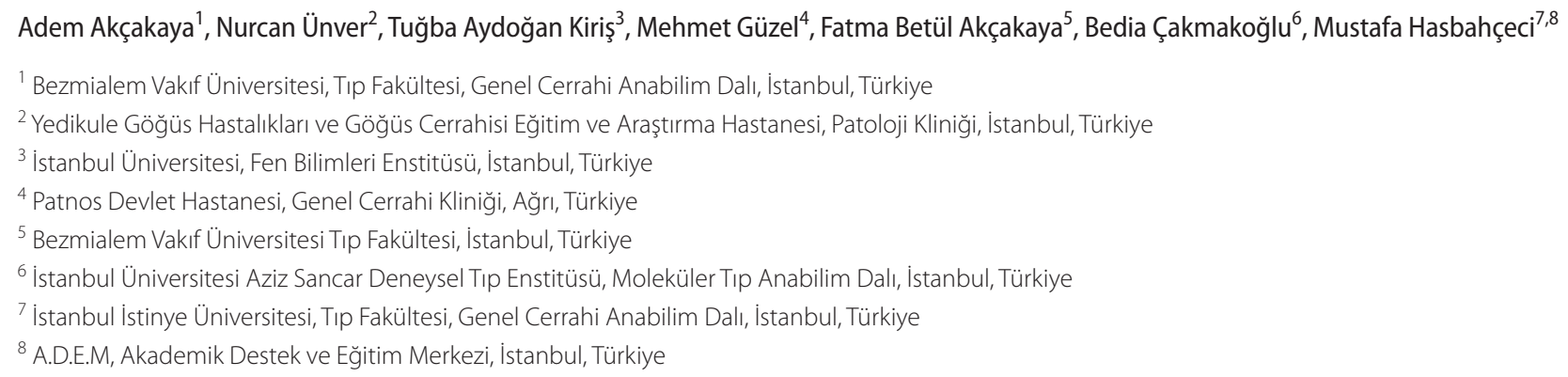

\section{ÖZET}

Giriş ve Amaç: E-kaderin (CDH1) geninin $-160 \mathrm{C} \rightarrow$ A ve $-347 \mathrm{G} \rightarrow \mathrm{GA}$ polimorfizmleri ile fonksiyon kaybı, mide kanseri için kritik bir adım olarak kabul edilmektedir. Bu polimorfizmlerin ve E-kaderin immünekspresyonunun mide kanseri ile olası ilişkisinin araştırılması amaçlandı.

Gereç ve Yöntem: Mide adenokarsinomu olan hastalar ve benign mide patolojileri olan bireyler bu vaka kontrol çalışmasına dahil edildi. Demografik veriler ve patolojik bulgular kaydedildi. E-kaderin ekspresyonunun immünohistokimyasal boyaması ve $-160 \mathrm{C} \rightarrow \mathrm{A}$ ve $-347 \mathrm{G} \rightarrow \mathrm{GA}$ polimorfizmlerinin analizi yapıldı. $-160 \mathrm{C} \rightarrow$ A ve $-347 \mathrm{G} \rightarrow$ GA polimorfizmlerinin allel frekansları ve E-kaderin ekspresyonu arasındaki farklar birincil sonuçlardı.

Bulgular: 78 mide kanseri hastası (Grup A) ve benign mide patolojisi olan 113 birey (Grup B) vardı. Erkek hasta sayısı ve ortalama yaş grup A'da daha yüksekti $(p<0,001)$. -160 C $\rightarrow$ A ve $347 \mathrm{G} \rightarrow$ GA polimorfizmleri ve allelik dağılımları gruplar arasında fark göstermedi (tümü için $p>0,05)$. $-160 C \rightarrow A$ polimorfizmi ile E-kaderin ekspresyonunun derecesi arasında anlamlı bir ilişki vardı $(p=0,013)$. $-160 C \rightarrow A, 347 \mathrm{G} \rightarrow \mathrm{GA}$ ile hayatta kalma oranları ve E-kaderin ekspresyonunun yoğunluğu arasında anlamlı fark yoktu (tümü için $p>0,05$ ). $-160 \mathrm{C} \rightarrow \mathrm{A}$ ve $-347 \mathrm{G} \rightarrow \mathrm{GA}$ polimorfizmleri ve mide kanseri arasında anlamlı bir ilişki yoktu.

Sonuç: E-kaderin ekspresyonunun tümör özellikleri ve mide kanserinin sağkalımı üzerine etkisi yoktu. $-160 \mathrm{C} \rightarrow \mathrm{A}$ polimorfizmi, mide kanserinde E-kaderin ekspresyonunu etkileyebilir.

Anahtar Kelimeler: $\mathrm{CDH1}$ polimorfizmleri, E-kaderin, gastrik karsinoma, immünhistokimyasal ekspresyon, sağkalım

Doi: $10.47717 /$ turkjsurg.2021.5097 